\title{
BEYOND RUST
}




\section{POLITICS AND CULTURE IN MODERN AMERICA}

Series Editors: Margot Canaday, Glenda Gilmore, Michael Kazin, Stephen Pitti, Thomas J. Sugrue

Volumes in the series narrate and analyze political and social change in the broadest dimensions from 1865 to the present, including ideas about the ways people have sought and wielded power in the public sphere and the language and institutions of politics at all levels-local, national, and transnational. The series is motivated by a desire to reverse the fragmentation of modern U.S. history and to encourage synthetic perspectives on social movements and the state, on gender, race, and labor, and on intellectual history and popular culture. 


\section{BEYOND RUST \\ Metropolitan Pittsburgh \\ and the Fate of Industrial America}

Allen Dieterich-Ward

$\overline{\text { PENN }}$

UNIVERSITY OF PENNSYLVANIA PRESS

PHILADELPHIA 
Copyright (C) 2016 University of Pennsylvania Press

All rights reserved. Except for brief quotations used for purposes of review or scholarly citation, none of this book may be reproduced in any form by any means without written permission from the publisher.

Published by

University of Pennsylvania Press

Philadelphia, Pennsylvania 19104-4112

www.upenn.edu/pennpress

Printed in the United States of America

on acid-free paper

$10 \quad 9 \quad 8 \quad 7 \quad 6 \quad 5 \quad 4 \quad 3 \quad 21$

Library of Congress Cataloging-in-Publication Data

Dieterich-Ward, Allen, author.

Beyond rust : metropolitan Pittsburgh and the fate of industrial America / Allen Dieterich-Ward.

pages $\mathrm{cm}-$ (Politics and culture in modern America)

Includes bibliographical references and index. ISBN 978-0-8122-4767-1 (alk. paper)

1. Urban renewal-Pennsylvania-Pittsburgh20th century. 2. Pittsburgh (Pa.)-Economic conditions-20th century. 3. Pittsburgh Metropolitan Area (Pa.)-Economic conditions20th century. 4. Community developmentPennsylvania-Pittsburgh. 5. Urban renewalUnited States-Case studies. 6. Community development, Urban-United States-Case studies. I. Title. II. Series: Politics and culture in modern America.

HT177.P5D54 2016 $307.3^{\prime} 4160974886-d c 23$ 